\title{
DEOXYRIBONUCLEASE ACTIVITY IN SEMEN
}

\author{
P. J. QUINN* \\ Department of Veterinary Physiology, University of Sydney, Sydney, Australia
}

(Received 13th September 1967, accepted 17th December 1967)

\begin{abstract}
Summary. The methyl green assay method has been used to determine the activity of DNase I and DNase II in ram, bull, human, dog and rabbit seminal plasma. The activity of DNase II was higher except in the ram. The DNase I activity of ram seminal plasma was inhibited by low concentrations of citrate, zinc and cetyltrimethylammonium bromide; this detergent also caused a reduction of DNase II activity. There was a stimulation of DNase I activity by $10 \mathrm{~mm}$-citrate but not by concentrations less than $2 \mathrm{~mm}$. Addition of antibiotics or shaking of ram seminal plasma with toluene did not affect the activity of either DNase. After deep freezing of ram semen there was a decrease of DNase I activity in the plasma and an increase of DNase I and II activity in extracts obtained from disintegrated spermatozoa. No significant change in DNase activity could be detected in the plasma of ram semen which had previously been subjected to cold shock.
\end{abstract}

\section{INTRODUCTION}

Reduced fertility of some mammalian spermatozoa has been attributed to a lower DNA content (Leuchtenberger, Weir, Schrader \& Murmanis, 1955; Leuchtenberger, Murmanis, Murmanis, Ito \& Weir, 1956; Salisbury \& Flerchinger, 1961) or to ageing of the sperm cell (Segina \& Norman, 1964; Anand, Hoekstra \& First, 1967). It was of interest, therefore, to determine the activity and properties of the enzymes most probably concerned with the degradation of DNA in spermatozoa. A reference to DNase in human semen has been previously made by Zamenhof, Shettles \& Chargaff (1950). In bull semen a deoxyribonuclease with a $\mathrm{pH}$ optimum about 6.2 has been reported by Waldschmidt, Karg \& Kinzler (1964). The latter enzyme was shown to be secreted in the ampullae; only low activity was detected in the spermatozoa. DNase is reported to cause a rapid decrease in the motility of human and dog spermatozoa (Berdyshev, Korochkin \& Yakutenok, 1965).

\section{MATERIALS AND METHODS}

Ram, bull, human, dog and rabbit semen was collected as described previously (Quinn, White \& Wirrick, 1965). Seminal plasma was separated from the spermatozoa by centrifuging the semen for $15 \mathrm{~min}$ at $4000 \mathrm{~g}$ with the temperature maintained at 20 to $25^{\circ} \mathrm{C}$, so as to avoid cold shock.

* Present address: Institute of Animal Physiology, Babraham, Cambridge. 
Deoxyribonuclease (DNase) activity was assayed by the release of methyl green bound to highly polymerized calf-thymus DNA (Sigma Chemical Co.). DNase I (alkaline DNase) activity was determined at $\mathrm{pH} 7.6$ as described by Kurnick (1953), and DNase II (acid DNase) at pH 4.6 (Kurnick \& Sandeen, 1960). The substrates and inhibitors were prepared as described by Kurnick (1962) except that merthiolate was omitted from the substrate which was stored at $2^{\circ} \mathrm{C}$ and prepared freshly each week. The reaction mixture was incubated at $37^{\circ} \mathrm{C}$, aliquots removed at $0,30,60,120,180$ and $240 \mathrm{~min}$, and the reaction inhibited with neutral citrate. After allowing the released methyl green to fade overnight, the rate of change in optical density at $640 \mathrm{~m} \mu$ was determined. A unit of enzyme activity is defined as that which causes a reduction of 1 O.D. unit $/ \mathrm{min}$.

Ram semen was 'cold-shocked' by placing samples held at $30^{\circ} \mathrm{C}$ into a cold water bath at $2^{\circ} \mathrm{C}$. Deep-freezing was carried out at $-79^{\circ} \mathrm{C}$, in finely crushed solid $\mathrm{CO}_{2}$. After $10 \mathrm{~min}$ all samples were thawed to $30^{\circ} \mathrm{C}$. The DNase activity of both frozen and non-frozen ram spermatozoa was determined after centrifuging the semen for $20 \mathrm{~min}$ at $5500 \mathrm{~g}$ and washing the spermatozoa once with $150 \mathrm{~mm}-\mathrm{NaCl}$. The spermatozoa were resuspended in cold saline and disintegrated for $90 \mathrm{sec}$ at $20 \mathrm{kcycles} / \mathrm{sec}$ in a Mullard ultrasonic disintegrator. Ultrasonic treatment is reported to accelerate the release of DNase from cell organelles (Okada \& Kallee, 1956). Penicillin and streptomycin $(0.5 \mathrm{mg} / \mathrm{ml}$ of each) were added to the sonicate which was incubated at $37^{\circ} \mathrm{G}$ for 3 days. Suitable aliquots were removed each day and DNase activities determined in the supernatant after centrifugation.

The results were analysed statistically by the analysis of variance and treatment comparisons made by $t$-tests using the interaction mean square to derive the standard error of the difference between means.

\section{RESULTS}

A preliminary experiment was designed to determine the range of enzyme concentrations at which the rate of the DNase I reaction was unaffected by the substrate-magnesium concentration. Aliquots $(0.1$ to $0.45 \mathrm{ml})$ of pooled ram seminal plasma were added to $15 \mathrm{ml}$ of the DNase I substrate mixture and made up to $19 \mathrm{ml}$ with $150 \mathrm{~mm}-\mathrm{NaCl}$. There was a linear relationship between the rate of change in optical density and the volume of seminal plasma between 0.1 and $0.45 \mathrm{ml}$ and subsequent assays of DNase I were, therefore, kept within these limits.

The activities of DNase I and DNase II in ram, bull, human, dog and rabbit seminal plasma are shown in Table 1. The activity of DNase II was higher than DNase I in the seminal plasma of all the species except the ram where the activity of the DNase I was more than three times higher than that of DNase II. Seminal plasma from the sperm-rich fraction of dog semen had a notably low activity of DNases.

The effect of citrate in concentrations up to $10 \mathrm{~mm}$, and of zinc up to $100 \mu \mathrm{M}$, on the activity of ram seminal plasma DNases was next investigated. The results (Table 2, Experiment 1) show a marked inhibition of DNase I with increasing 
concentrations of citrate and zinc, the latter giving comparable inhibition in concentrations nearly 100 times less than citrate. Since the measurement of DNase activity in spermatozoa necessitated incubation for several days the

TABLE 1

THE ACTIVITY OF DEOXYRIBONUCLEASES IN THE SEMINAL PLASMA OF VARIOUS SPECIES

\begin{tabular}{l|c|c}
\hline \multirow{2}{*}{ Species } & \multicolumn{2}{|c}{ DNase units $\times 10^{-4} / \mathrm{ml}$} \\
\cline { 2 - 3 } & DNase I & DNase II \\
\hline Ram (12) & $730 \pm 175$ & $231 \pm 80$ \\
Bull (4) & $49 \pm 13$ & $100 \pm 6$ \\
Human (4) & $248 \pm 20$ & $376 \pm 66$ \\
Dog*(3) & $3 \cdot 8 \pm 0 \cdot 26$ & $34 \pm 6 \cdot 5$ \\
Rabbit (3) & $58 \pm 30$ & $98 \pm 64$ \\
\hline
\end{tabular}

Mean values \pm s.e. are given for the number of replicates in parentheses.

* Plasma from the sperm-rich fraction.

effect of adding substances which prevent microbial growth on the activity of ram seminal plasma DNases was determined (Table 2, Exp. 2). The presence of antibiotics or shaking of ram seminal plasma with an equal volume of toluene

TABLE 2

THE EFFECT OF CITRATE, ZINC, ANTIBIOTICS, CTAB AND TOLUENE ON THE ACTIVITY OF DEOXYRIBONUCLEASES IN RAM SEMINAL PLASMA

\begin{tabular}{|c|c|c|c|c|}
\hline \multirow{2}{*}{ Experiment } & \multirow{2}{*}{ Substance } & \multirow{2}{*}{$\begin{array}{l}\text { Concentration in } \\
\text { reaction mixture }\end{array}$} & \multicolumn{2}{|c|}{ DNase units $\times 10^{-4} / \mathrm{ml}$} \\
\hline & & & DNase $I$ & DNase $I I$ \\
\hline \multirow[t]{2}{*}{1} & Citrate & $\begin{array}{r}- \\
1 \overline{\mathrm{mM}} \\
2 \mathrm{mM} \\
10 \mathrm{mM}\end{array}$ & $\begin{array}{l}696 \\
375 \\
113^{*} \\
0^{* *}\end{array}$ & $\begin{array}{c}577 \\
583 \\
549 \\
1005^{* *}\end{array}$ \\
\hline & Zinc & $\begin{array}{r}10 \overline{\mu \mathrm{M}} \\
20 \mu \mathrm{M} \\
100 \mu \mathrm{M}\end{array}$ & $\begin{array}{l}639 \\
394 * * \\
215^{* *} \\
19 * *\end{array}$ & $\begin{array}{l}274 \\
311 \\
282 \\
193\end{array}$ \\
\hline \multirow[t]{2}{*}{2} & Nil & 一 & 715 & 187 \\
\hline & $\begin{array}{l}\text { penicillin } \\
\text { cTaB } \\
\text { Toluene }\end{array}$ & $\begin{array}{c}150 \mu \mathrm{g} \mathrm{each} / \mathrm{ml} \\
650 \mu \mathrm{M}\end{array}$ & $\begin{array}{l}725 \\
452 * * \\
709\end{array}$ & $\begin{array}{l}201 \\
99 * * \\
172\end{array}$ \\
\hline
\end{tabular}

* $P<0.05 ;{ }^{* *} P<0.01$ (significantly different from controls), values are means of three replicates.

had little effect on the activity of DNases. A similar treatment of ram spermatozoa sonicates with toluene was also without effect on DNase activity of the supernatant. The detergent cetyltrimethylammonium bromide (CTAB), however, caused a marked depression of the activity of DNase I and II.

In the next experiment the activity of DNases was measured in the seminal 
plasma of cold-shocked and deep-frozen ram semen. There were no significant changes after cold shock (792 and $728 \times 10^{-4}$ DNase I units $/ \mathrm{ml}$, and 105 and $71 \times 10^{-4}$ DNase II units $/ \mathrm{ml}$, in the control and cold-shocked material respectively), but after deep-freezing, the activity of DNase I significantly decreased (605 and $92 \times 10^{-4}$ units/ml of DNase I and II respectively). The activity of DNases in the spermatozoa obtained from frozen and non-frozen ram semen was determined during a 3-day incubation at $37^{\circ} \mathrm{C}$. There was a marked increase of DNase I and DNase II activity in the sonicate supernatant from the frozen but not from the non-frozen spermatozoa after a l-day incubation. During subsequent incubation of frozen spermatozoa there was a decrease in DNase I activity, but a further progressive increase of DNase II. A slight increase in both enzymic activities was observed in non-frozen spermatozoa after 2 days of incubation.

\section{DISCUSSION}

The release of DNA-bound methyl green by deoxyribonuclease has proved a sensitive and reliable method for the estimation of DNases in seminal plasma. In general, there were considerable sample variations in DNase activity, particularly in ram seminal plasma in which activities of DNase I ranged from 444 to $1201 \times 10^{-4}$ units $/ \mathrm{ml}$, and DNase II from 47 to $672 \times 10^{-4}$ units $/ \mathrm{ml}$. The inhibition of DNase by citrate and zinc at high $\mathrm{pH}$ only, is an indication of the existence of two enzymes (Laskowski, 1961). DNase I of ram seminal plasma is particularly sensitive to inhibition by zinc but not by citrate (Gilbert, Overend, \& Webb, 1951; Oth, Fredericq \& Hacha, 1958). High concentrations of citrate in mammalian semen and of zinc in human (Mawson \& Fischer, 1956) and dog semen (Bartlett, 1958) would reduce the activity of DNase I. At normal $\mathrm{pH}$ and ionic concentration of seminal plasma, DNase II activity would also be reduced.

The lower DNase I activity of ram seminal plasma which had been separated from deep-frozen semen may be the result of increased membrane permeability, and of an uptake of the enzyme by spermatozoa, as indicated by an increase of DNase I activity in the spermatozoa as such. DNase II probably also enters the spermatozoa during freezing.

\section{ACKNOWLEDGMENTS}

The author is grateful to Professor C. W. Emmens and Dr I. G. White for their interest and advice. The work has been aided by grants from the Ford Foundation, the Australian Dairy Produce Board and support from a Royal Agricultural Society (N.S.W.) Fellowship during 1967.

\section{REFERENCES}

Anand, A. S., Hoekstra, W. G. \& First, N. L. (1967) Effect of ageing of boar spermatozoa on cellular loss of DNA. 7. Anim. Sci. 26, 171.

BartLetr, D. J. (1958) Biochemical characteristics of dog semen. Nature, Lond. 182, 1605.

Berdyshev, G. D., Korochkin, L. I. \& Yakutenok, A. V. (1965) The effect of deoxyribonuclease on the mobility of spermatozoa. In: The Cytochemistry of Nucleic Acids under Normal and Pathological Conditions, p. 20. Tomskii Univ. Tomsk. 
Gilbert, L. M., Overend, W. G. \& Webb, M. (1951) The inhibition of pancreatic deoxyribonuclease. Expl Cell Res. 2, 349.

Kurnick, N. B. (1953) Desoxyribonuclease activity of sera of man and some other species. Archs Biochem. Biophys. 43, 97.

Kurnick, N. B. (1962) Assay of deoxyribonuclease activity. In: Methods of Biochemical Analysis, Vol. 9, p. 1. Ed. David Glick. Wiley, New York.

KurNick, N. B. \& SANDEEN, G. (1960) Acid desoxyribonuclease assay by the methyl green method. Biochim. biophys. Acta, 39, 226.

LAskowski, M. (1961) Deoxyribonucleases. In: The Enzymes, Vol. 5, p. 123. Eds. P. D. Boyer, H. Lardy and K. Myrback. Academic Press, New York.

Leuchtenderger, C., Murmanis, I., Murmanis, L., Ito, S. \& Weir, D. R. (1956) Interferometric dry mass and microspectrophotometric arginine determination in bull sperm nuclei with normal and abnormal DNA content. Chromosoma, 8, 73.

Leuchtenderger, G., Weir, B. R., Schrader, F. \& Murmanis, L. (1955) The desoxyribosenucleic acid (DNA) content of repeated seminal fluids from fertile and infertile men. F. Lab. clin. Med. 45,851 .

MAwson, C. A. \& Fischer, M. I. (1956) Zinc in aspermic human semen. Nature, Lond. 177, 190.

OkadA, S. \& KalleE, E. (1956) Effect of X-rays on mitochondrial deoxyribonuclease II. Expl Cell Res. $11,212$.

Oth, A., Frederice, E. \& HAChA, R. (1958) Enzymic degradation of deoxyribonucleic acid. II. Enzymic properties of thymus acid deoxyribonuclease. Biochim. biophys. Acta, 29, 287.

QunN, P. J., WhITE, I. G. \& WIRRICK, B. R. (1965) Studies of the distribution of the major cations in semen and male accessory secretions. F. Reprod. Fert. 10, 379.

SAlisbury, G. W. \& Flerchinger, F. H. (1961) In-vitro ageing of spermatozoa and evidence for embryonic or early fetal mortality in cattle. Proc. IVth int. Congr. Anim. Reprod., The Hague, 3, 601.

Segina, M. R. \& Norman, G. (1964) Age-related changes in the DNA of bovine sperm. Proc. Vth int. Congr. Anim. Reprod. A.I., Trento, 4, 276.

Waldschmid, M., KARG, H. \& KinzLeR, M. (1964) Vorkommen von Desoxyribonuklease in mannlichen Geschlechtssekreten beim Rind. Naturwissenschaften, 51, 364.

Zamenhop, S., Shetrles, L. B. \& Chargafr, E. (1950) Isolation of deoxypentose nucleic acid from human sperm. Nature, Lond. 165, 765. 